\title{
Protective effects of Lagerstroemia speciosa on 3-morpholinosydnonimine (SIN-1)-induced oxidative stress in HIT-T15 pancreatic $\beta$ cells
}

\author{
JIA-LE SONG $^{1 *}$, XIN ZHAO $^{1,2}$, QIANG WANG ${ }^{2}$ and TING ZHANG ${ }^{3 *}$ \\ ${ }^{1}$ Department of Food Science and Nutrition, Pusan National University, Busan 609-735, Republic of Korea; \\ ${ }^{2}$ Department of Biological and Chemical Engineering, Chongqing University of Education, Chongqing 400067; \\ ${ }^{3}$ Research Center for Nutrition and Food Safety, The Third Military Medical University, \\ Chongqing Key Laboratory of Nutrition and Food Safety, Chongqing 400038, P.R. China
}

Received November 15, 2012; Accepted March 19, 2013

DOI: $10.3892 / \mathrm{mmr} .2013 .1396$

\begin{abstract}
Reactive oxygen species (ROS)-induced pancreatic $\beta$ cell death affects insulin secretion and is important in the pathogenesis of diabetes. Lagerstroemia speciosa, a traditional folk medicine, has been used for $\mathrm{t}$ he prevention and treatment of diabetes. However, whether Lagerstroemia speciosa has a cytoprotective effect on pancreatic $\beta$ cells remains to be elucidated. The present study aimed to investigate the cytoprotective effects of hot water extracts from Lagerstroemia speciosa leaves (LWE) on 3-morpholinosydnonimine (SIN-1)-induced oxidative damage in Syrian hamster pancreatic insulinoma HIT-T15 cells. The HIT-T15 cells were first treated with SIN-1 $(50 \mu \mathrm{M})$ for $24 \mathrm{~h}$ and then co-incubated with LWE for $48 \mathrm{~h}$. SIN-1 significantly decreased HIT-T15 cell viability $(\mathrm{P}<0.05)$; however, LWE did not exert a significant cytotoxic effect and increased the viability of HIT-T15 cells in a dose-dependent manner. To further investigate the protective effects of LWE on SIN-1-induced oxidative stress in HIT-T15 cells, the cellular levels of ROS, lipid peroxidation and endogenous antioxidant enzymes, including superoxide dismutase (SOD), catalase (CAT) and glutathione peroxidase (GSH-px), were determined. LWE decreased the intracellular levels of ROS and lipid peroxidation, and increased the activities of antioxidant enzymes. These results suggest that LWE has a cytoprotective effect against SIN-1-induced oxidative stress in HIT-T15 cells through the inhibition of lipid peroxidation, a decrease in ROS levels and an increase in antioxidant enzyme activity. In addition, LWE increased insulin secretion in SIN-1-treated
\end{abstract}

Correspondence to: Dr Xin Zhao, Department of Biological and Chemical Engineering, Chongqing University of Education, No. 9 Xuefu Main Street, Nan'an, Chongqing 400067, P.R. China E-mail: zhaoxin@pnu.edu

*Contributed equally

Key words: Lagerstroemia speciosa, pancreatic $\beta$ cell, cell viability, reactive oxygen species, insulin secretion
HIT-T15 cells. Our results suggested that LWE were effective in the treatment of diabetes. Further studies are required to study the anti-diabetic molecular mechanism in a cell model.

\section{Introduction}

Diabetes mellitus has become an increasingly important public health problem worldwide. However, the etiology of diabetes mellitus has not yet been fully elucidated. Reactive oxygen species (ROS)-induced oxidative stress is known to be important in the pathogenic process of diabetes mellitus. ROS that are particularly responsible for oxidative stress include superoxide $\left(\mathrm{O}_{2}^{-}\right)$, hydroxyl radical $\left({ }^{\circ} \mathrm{OH}\right)$, singlet oxygen $\left({ }^{1} \mathrm{O}_{2}\right)$, hydrogen peroxide $\left(\mathrm{H}_{2} \mathrm{O}_{2}\right)$, nitric oxide $(\mathrm{NO})$ and peroxynitrite $\left(\mathrm{ONOO}^{-}\right)$(1). Oxidative stress may induce the dysfunction of pancreatic $\beta$ cells, decreased insulin secretion (2) and the development of diabetic complications, including retinopathy, nephropathy, neuropathy and vascular damage $(3,4)$. Generally, various antioxidative compounds exist in mammalian cells, including low-molecular mass antioxidants such as glutathione (GSH), uric acid, vitamin $\mathrm{C}$, vitamin $\mathrm{E}$ and various endogenous antioxidant enzymes against oxidative stress. It is widely accepted that superoxide dismutase (SOD), catalase (CAT) and glutathione peroxidase (GSH-px) are three important endogenous antioxidant enzymes for the protection of living organs against ROS-induced oxidative stress. Among these antioxidant enzymes, SOD catalyzes the dismutation of $\mathrm{O}_{2}^{-}$into $\mathrm{H}_{2} \mathrm{O}_{2}$, which may be transformed into $\mathrm{H}_{2} \mathrm{O}$ and $\mathrm{O}_{2}$ by CAT. GSH-px is crucial for removing lipid hydroperoxides and reducing free $\mathrm{H}_{2} \mathrm{O}_{2}$ to water (1).

A number of drugs used in clinical diabetes mellitus treatment have been associated with side-effects, including gastrointestinal disturbances, edema, myocardial infarction and risk of cardiovascular disease (5-8). To date, $>400$ traditional plant treatments for diabetes mellitus have been identified (9). The anti-diabetic components of these natural plants may constitute ancillary medication for diabetes treatment.

Lagerstroemia speciosa (Lythraceae), also named banaba, is a tropical plant that grows in several parts of southeast Asia, including southern China, Vietnam, 
Malaysia and the Philippines. Lagerstroemia speciosa has been used as a traditional folk medicine for the treatment of diabetes and kidney-related diseases in the Philippines for $\sim 1,000$ years $(10,11)$. A number of studies have reported that Lagerstroemia speciosa has antioxidant $(12,13)$, anti-inflammatory (13), anticancer (14), anti-obesity (15) and antidiabetic $(12,16)$ activities. Tannic and triterpene acids are the main components of Lagerstroemia speciosa leaf extracts and have been shown to downregulate blood glucose and possess apparent antidiabetic properties in vivo and in vitro (16-19).

The present study aimed to investigate the potential cytoprotective effects of hot water extracts from Lagerstroemia speciosa leaves (LWE) on 3-morpholinosydnonimine (SIN-1)-induced oxidative stress in HIT-T15 cells and to elucidate the underlying mechanisms involved in this process.

\section{Materials and methods}

Plant extract preparation. Fresh Lagerstroemia speciosa leaves were purchased from a local market in Chongqing, China. LWE was prepared by boiling $160 \mathrm{~g}$ air-dried Lagerstroemia speciosa leaves in 11 distilled water for $2 \mathrm{~h}$, followed by ultracentrifugation at $30,000 \mathrm{x}$ g for $30 \mathrm{~min}$, filtration with a $0.4-\mu \mathrm{m}$ filter, concentration by heat evaporation and freeze-drying. LWE was redissolved in dimethyl sulfoxide (DMSO) at a concentration of $50 \mathrm{mg} / \mathrm{ml}$ and stored at $4^{\circ} \mathrm{C}$ until future use.

Cell culture. Syrian hamster insulin-secreting HIT-T15 cells were obtained from the American Type Culture Collection (ATCC, Manassas, VA, USA). The cells were routinely maintained in RPMI-1640 medium supplemented with $10 \%(\mathrm{v} / \mathrm{v})$ fetal bovine serum (FBS) and $1 \%$ penicillin-streptomycin in a humidified $\mathrm{CO}_{2}$ incubator (model 3154; Forma Scientific, Inc. Marietta, $\mathrm{OH}, \mathrm{USA}$ ) with $5 \% \mathrm{CO}_{2}$ at $37^{\circ} \mathrm{C}$.

Cell viability assay. Cell viability was assessed using the 3-(4,5-dimethylthiazol-2-yl)-2,5-diphenyl tetrazolium bromide (MTT) method. The cells were seeded in 96-well plates at a density of $5 \times 10^{3}$ cells/well. Following 24-h incubation, the cells were primarily treated with SIN-1 $(50 \mu \mathrm{M})$ for $24 \mathrm{~h}$ and then incubated with LWE (1-100 $\mu \mathrm{g} / \mathrm{ml})$ for $48 \mathrm{~h}$. Next, $100 \mu \mathrm{l}$ MTT reagent (final concentration, $0.5 \mathrm{mg} / \mathrm{ml}$ ) was added to each well and the cells were incubated in a humidified incubator at $37^{\circ} \mathrm{C}$ to allow MTT to be metabolized. After $4 \mathrm{~h}$, $100 \mu \mathrm{l}$ DMSO was added to each well to dissolve formazan deposits. The absorbance of the samples was measured at a wavelength of $540 \mathrm{~nm}$ using a microplate reader (model 680; Bio-Rad, Hercules, CA, USA).

Determination of intracellular ROS. Intracellular ROS levels were measured using the fluorescent probe dihydrodichlorofluorescein $\left(\mathrm{H}_{2} \mathrm{DCFDA}\right)$. Following treatment, HIT-T15 cells were washed with calcium- and magnesium-free phosphate-buffered saline (PBS) and incubated in $\mathrm{H}_{2}$ DCFDA $(20 \mu \mathrm{M})$ containing serum- and phenol red-free Dulbecco's modified Eagle's medium (DMEM) for $30 \mathrm{~min}$. Following incubation, the medium was removed and cells were washed with PBS twice. Fluorescence was measured using a FLUOstar
OPTIMA fluorescence plate reader (BMG Labtech, Ortenberg, Germany); excitation was read at $485 \mathrm{~nm}$ and emission at $535 \mathrm{~nm}$. Relative ROS production (calculated as a percentage of the control) was expressed as the ratio of fluorescence in the treated samples over the response in the appropriate controls:

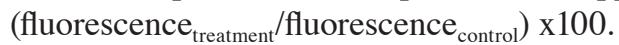

Lipid peroxidation levels. Lipid peroxidation was evaluated using a thiobarbituric acid reactive substance (TBARS) assay (20). Briefly, the cultured cells were washed with cooled PBS, scraped into trichloroacetic acid (TCA; 2.8\%, w/v) and sonicated; total protein was determined using a bicinchoninic acid (BCA) assay. The suspension was mixed with $1 \mathrm{ml}$ TBA $(0.67 \%, \mathrm{w} / \mathrm{v})$ and $1 \mathrm{ml} \mathrm{TCA}(25 \%, \mathrm{w} / \mathrm{v})$, heated $(30 \mathrm{~min}$ at $\left.95^{\circ} \mathrm{C}\right)$ and centrifuged $\left(22,000 \mathrm{x} \mathrm{g} ; 10 \mathrm{~min}\right.$ at $\left.4^{\circ} \mathrm{C}\right)$. TBA reacted with the oxidative degradation products of lipids, yielding red complexes that absorbed at $535 \mathrm{~nm}$. The level of TBARS was determined using a UV-2401PC spectrophotometer (Shimadzu, Kyoto, Japan).

Antioxidant enzyme activity. HIT-T15 cells grown in a $10-\mathrm{cm}$ cell culture dish were co-incubated with SIN-1 $(50 \mu \mathrm{M})$ for $24 \mathrm{~h}$ and then treated with LWE $(2.5-50 \mu \mathrm{g} / \mathrm{ml})$ for $48 \mathrm{~h}$ for further assessment. The cells were washed with PBS, removed by scraping and centrifuged, and the resulting cell pellet was stored at $-80^{\circ} \mathrm{C}$. Cell pellets were thawed, resuspended in $300 \mathrm{ml}$ cold lysis buffer (PBS and $1 \mathrm{mM}$ EDTA), homogenized and centrifuged $\left(22,000 \mathrm{x} \mathrm{g} ; 10 \mathrm{~min}\right.$ at $\left.4^{\circ} \mathrm{C}\right)$. The resulting supernatants were used for activity measurements. CAT activity (U/mg protein) was assessed according to the method described by Nelson and Kiesow (21), in which the disappearance of the substrate $\mathrm{H}_{2} \mathrm{O}_{2}$ was measured spectophotometrically at $240 \mathrm{~nm}$. SOD activity (U/mg protein) was assayed using a modified auto-oxidation of pyrogallol method (22). One unit of SOD activity was defined as the amount of enzyme that inhibited the auto-oxidation rate of pyrogallol by $50 \%$. GSH-px activity (U/mg protein) was assayed according to the method described by Hafemen et al (23). Protein contents were determined using the Bio-Rad protein assay kit according to the manufacturer's instructions.

Insulin secretion assay. Insulin secretion was measured using a radioimmunoassay (RIA) method. The cells were seeded at a density of $5 \times 10^{5}$ cells/well in a 96 -well plate and primarily treated with SIN-1 $(50 \mu \mathrm{M})$ for $24 \mathrm{~h}$, followed by $\operatorname{LWE}(2.5-50 \mu \mathrm{g} / \mathrm{ml})$ for $48 \mathrm{~h}$. To determine the level of insulin secreted, aliquots of samples ( $10 \mu \mathrm{l} /$ well) were collected from the experimental medium at the indicated time points (48 h) and subjected to an insulin antiserum immunoassay within 5 min, according to the manufacturer's instructions (Linco Research, Inc., St. Charles, MO, USA). The absorbance was read at 450 and $590 \mathrm{~nm}$ using a model 680 microplate reader (Bio-Rad) and results were recorded.

Statistical analysis. Data are presented as the mean \pm SD. The differences between the mean values of individual groups were assessed using one-way ANOVA and Duncan's multiple range tests. $\mathrm{P}<0.05$ was considered to indicate a statistically significant difference. The SAS v9.1 statistical software package (SAS Institute, Inc., Cary, NC, USA) was used for analysis. 


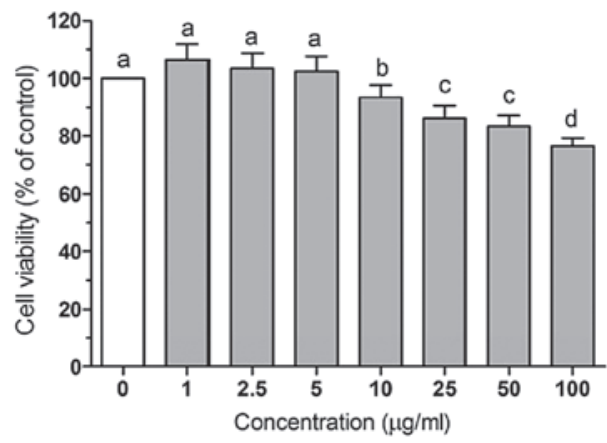

Figure 1. Effects of hot water extracts from Lagerstroemia speciosa leaves (LWE) on the cell viability of HIT-T15 pancreatic cells. Data are representative of three independent experiments and are expressed as the mean \pm SD. ${ }^{\mathrm{a}-\mathrm{d}}$ Mean values with different letters on the bars are significantly different $(\mathrm{P}<0.05)$ according to Duncan's multiple range test.

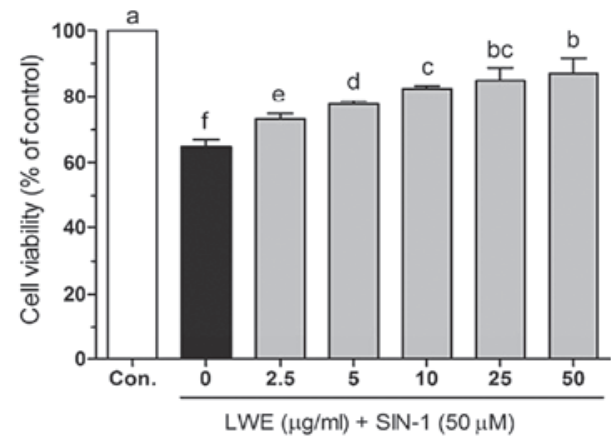

Figure 2. Effects of hot water extracts from Lagerstroemia speciosa leaves (LWE) on the cell viability of SIN-1-treated HIT-T15 pancreatic cells. Data are representative of three independent experiments and are expressed as the mean \pm SD. ${ }^{a-f}$ Mean values with different letters on the bars are significantly different $(\mathrm{P}<0.05)$ according to Duncan's multiple range test. SIN-1, 3-morpholinosydnonimine.

\section{Results}

Effects of LWE on SIN-1-induced oxidative damage in HIT-T15 cells. To investigate LWE-induced cytotoxicity, HIT-T15 cells were first treated with various concentrations of LWE $(1-100 \mu \mathrm{g} / \mathrm{ml})$ for $48 \mathrm{~h}$ and the cell viability was determined using an MTT assay. Treatment with LWE at doses of $1-50 \mu \mathrm{g} / \mathrm{ml}$ at $37^{\circ} \mathrm{C}$ for $48 \mathrm{~h}$ did not cause significant cytotoxicity and cell viability was $>80 \%$. A dose of $100 \mu \mathrm{g} / \mathrm{ml} \mathrm{LWE}$ induced cell damage (cell viability, 76\%; Fig. 1). Based on these results, concentrations of 2.5-50 $\mu \mathrm{g} / \mathrm{ml}$ LWE were used for further assessment. As shown in Fig. 2, SIN-1 (50 $\mu \mathrm{M})$ significantly induced cell death in HIT-T15 cells. However, following treatment with various concentrations of LWE, the cell viability increased in a dose-dependent manner.

Effects of LWE against SIN-1-induced intracellular ROS levels in HIT-T15 cells. To investigate the protective effects of LWE in SIN-1-treated HIT-T15 cells, the intracellular ROS levels were determined using the fluorescent probe $\mathrm{H}_{2}$ DCFDA. As shown in Fig. 3, SIN-1 significantly increased ROS levels compared with those in the control cells. In the presence of SIN-1, LWE at doses of $2.5-50 \mu \mathrm{g} / \mathrm{ml}$ significantly reduced

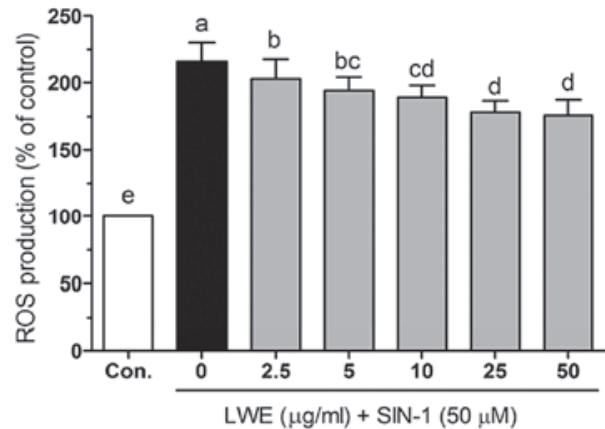

Figure 3. Effects of hot water extracts from Lagerstroemia speciosa leaves (LWE) on intracellular ROS levels in SIN-1-treated HIT-T15 pancreatic cells. Data are representative of three independent experiments and are expressed as the mean \pm SD. ${ }^{\mathrm{a} e}$ Mean values with different letters on the bars are significantly different $(\mathrm{P}<0.05)$ according to Duncan's multiple range test. ROS, reactive oxygen species; SIN-1, 3-morpholinosydnonimine.

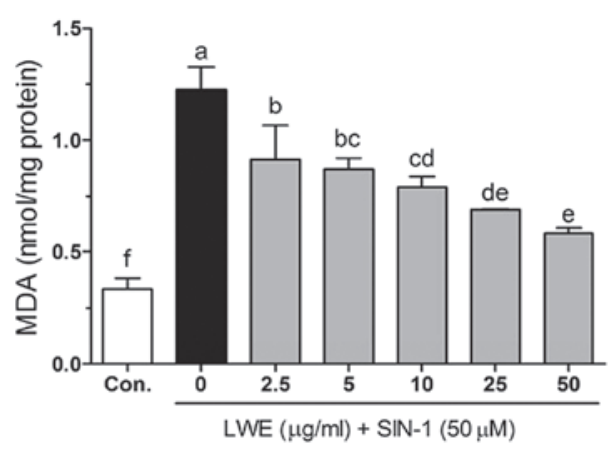

Figure 4. Effects of hot water extracts from Lagerstroemia speciosa leaves (LWE) on intracellular malondialdehyde (MDA) levels in SIN-1-treated HIT-T15 pancreatic cells. Data are representative of three independent experiments and are expressed as the mean \pm SD. ${ }^{\mathrm{a}-\mathrm{f}}$ Mean values with different letters on the bars are significantly different $(\mathrm{P}<0.05)$ according to Duncan's multiple range test. SIN-1, 3-morpholinosydnonimine.

ROS generation in a dose-dependent manner. The intracellular ROS levels were 203.2 $\pm 14.6,194.3 \pm 9.9,188.3 \pm 9.8,178.3 \pm 7.5$ and $175.7 \pm 10.8 \%$ when the cells were treated with $2.5,5,10$, 25 and $50 \mu \mathrm{g} / \mathrm{ml} \mathrm{LWE}$, respectively. Treatment with the same concentrations of LWE alone did not significantly increase the intracellular ROS levels (date not shown). These results suggest that LWE is a free radical scavenger.

Effects of LWE on lipid peroxidation in SIN-1-treated HIT-T15 cells. Free radical- and ROS-induced oxidative damage has been strongly associated with the lipid peroxidation of cell membranes and increased levels of malondialdehyde (MDA), which is a biomarker of cell membrane lipid peroxidation. As shown in Fig. 4, SIN-1 significantly increased the level of MDA $(1.23 \pm 0.10 \mathrm{nmol} / \mathrm{mg}$ protein) compared with that in the control cells $(0.33 \pm 0.05 \mathrm{nmol} / \mathrm{mg}$ protein $)$. LWE at doses of $2.5-50 \mu \mathrm{g} / \mathrm{ml}$ significantly reduced MDA levels in a dose-dependent manner. The MDA levels were $0.91 \pm 0.15,0.87 \pm 0.05,0.79 \pm 0.05$, $0.69 \pm 0.01$ and $0.58 \pm 0.02 \mathrm{nmol} / \mathrm{mg}$ protein when the cells were treated with $2.5,5,10,25$ and $50 \mu \mathrm{g} / \mathrm{ml} \mathrm{LWE}$, respectively.

Effects of LWE on the activity of antioxidant enzymes in SIN-1-treated HIT-T15 cells. Figs. 5-7 demonstrate the intracel- 


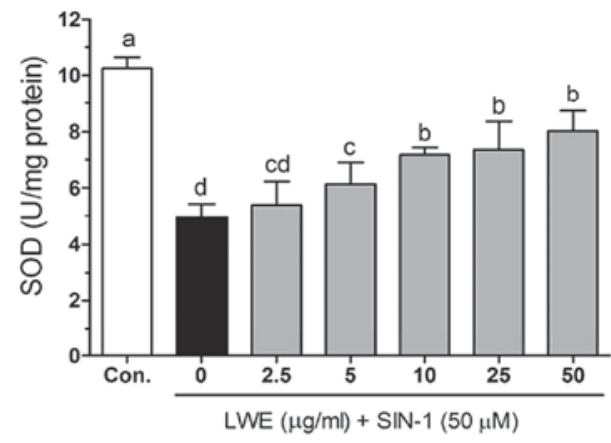

Figure 5. Effects of hot water extracts from Lagerstroemia speciosa leaves (LWE) on superoxide dismutase (SOD) levels in SIN-1-treated HIT-T15 pancreatic cells. Data are representative of three independent experiments and are expressed as the mean $\pm \mathrm{SD}$. ${ }^{\mathrm{a}-\mathrm{d}}$ Mean values with different letters on the bars are significantly different $(\mathrm{P}<0.05)$ according to Duncan's multiple range test. SIN-1, 3-morpholinosydnonimine.

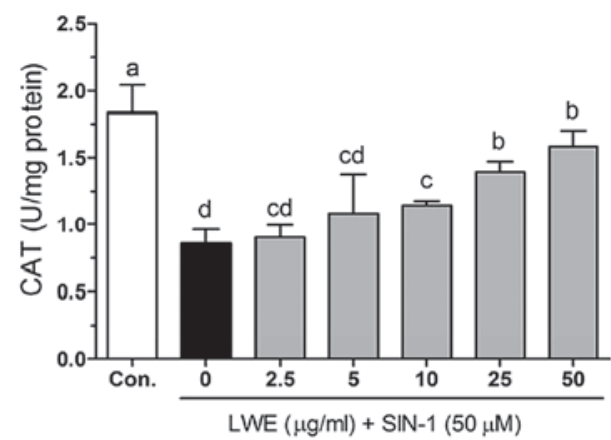

Figure 6. Effects of hot water extracts from Lagerstroemia speciosa leaves (LWE) on catalase (CAT) levels in SIN-1-treated HIT-T15 pancreatic cells. Data are representative of three independent experiments and are expressed as the mean $\pm \mathrm{SD}$. ${ }^{\mathrm{a}-\mathrm{d}}$ Mean values with different letters on the bars are significantly different $(\mathrm{P}<0.05)$ according to Duncan's multiple range test. SIN-1, 3-morpholinosydnonimine.

lular antioxidant enzyme activities with LWE in SIN-1-treated HIT-T15 cells. The activity of SOD was decreased with SIN-1 treatment $(4.96 \pm 0.46 \mathrm{U} / \mathrm{mg}$ protein) compared with that in the control cells; however, this recovered to $5.39 \pm 0.83$, $6.13 \pm 0.78,7.19 \pm 0.26,7.37 \pm 0.99$ and $8.04 \pm 0.73 \mathrm{U} / \mathrm{mg}$ protein when the cells were treated with $2.5,5,10,25$ and $50 \mu \mathrm{g} / \mathrm{ml}$ LWE, respectively. Following treatment with SIN-1, cellular CAT was decreased $(0.86 \pm 0.10 \mathrm{U} / \mathrm{mg}$ protein) compared with that in the control cells $(1.83 \pm 0.21 \mathrm{U} / \mathrm{mg}$ protein). However, CAT activity was significantly increased $(\mathrm{P}<0.05)$ following treatment with LWE (Fig. 6). Additionally, LWE reduced the SIN-1-induced decrease in GSH-px in HIT-T15 cells. The GSH-px activity was identified to be significantly increased from $1.93 \pm 0.17$ to $2.63 \pm 0.17 \mathrm{U} / \mathrm{mg}$ protein when the cells were treated with LWE (Fig. 7).

Effects of LWE on insulin secretion in SIN-1-treated HIT-T15 cells. As shown in Fig. 8, SIN-1 significantly decreased insulin levels $(2095.4 \pm 105.0 \mathrm{pg} / \mathrm{ml})$ compared with those in the control cells $(10236.7 \pm 98.9 \mathrm{pg} / \mathrm{ml})$. Following treatment with $2.5,5,10,25$ and $50 \mu \mathrm{g} / \mathrm{ml} \mathrm{LWE}$, the insulin levels were $2433.7 \pm 34.5,2824.2 \pm 150.3,3565.4 \pm 223.3,4730.9 \pm 140.3$ and $5069.2 \pm 131.5 \mathrm{pg} / \mathrm{ml}$, respectively. These results suggest that

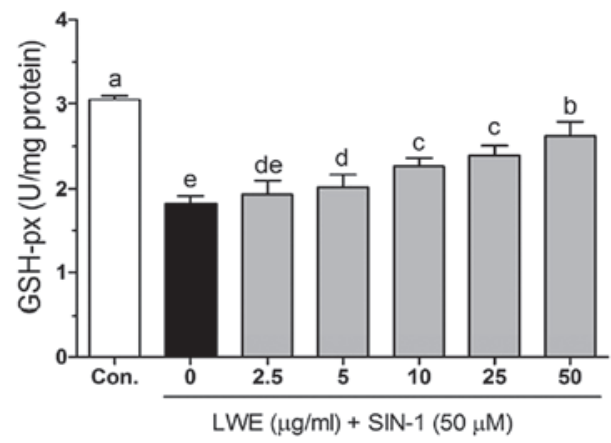

Figure 7. Effects of hot water extracts from Lagerstroemia speciosa leaves (LWE) on glutathione peroxidase (GSH-px) levels in SIN-1-treated HIT-T15 pancreatic cells. Data are representative of three independent experiments and are expressed as the mean $\pm \mathrm{SD}$. ${ }^{\mathrm{a}-\mathrm{e}}$ Mean values with different letters on the bars are significantly different $(\mathrm{P}<0.05)$ according to Duncan's multiple range test. SIN-1, 3-morpholinosydnonimine.

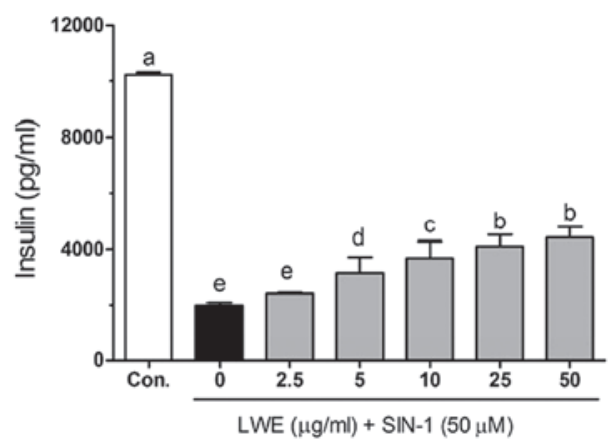

Figure 8. Effects of hot water extracts from Lagerstroemia speciosa leaves (LWE) on insulin levels in SIN-1-treated HIT-T15 pancreatic cells. Data are representative of three independent experiments and are expressed as the mean \pm SD. ${ }^{a-e}$ Mean values with different letters on the bars are significantly different $(\mathrm{P}<0.05)$ according to Duncan's multiple range test. SIN-1, 3-morpholinosydnonimine.

LWE treatment is effective in increasing pancreatic $\beta$ cell survival and maintaining normal biological functions in ROS-induced diabetes.

\section{Discussion}

ROS-induced oxidative damage in pancreatic $\beta$ cells is considered to be important in the pathological process of diabetes. A number of studies have shown that reducing ROS levels and treatment with antioxidants (including NAC, vitamin C and vitamin E) improved $\beta$ cell structure and function in vitro $(24,25)$. However, whether LWE protects pancreatic $\beta$ cells against SIN-1-induced oxidative damage has not yet been elucidated. In the present study, we demonstrated that LWE protected HIT-T15 cells against ROS-induced cell damage. The cytoprotective effects of LWE were mainly mediated by increased intracellular antioxidant enzyme activity.

The results of this study clearly showed that LWE prevented SIN-1-induced cell death, as assessed using the MTT assay. Additionally, LWE alone was not significantly cytotoxic to cells at the concentrations used. Treatment with LWE was shown to have a significant protective effect, which may be attributed to the free radical scavenging activity of the extract. 
To evaluate the role of free radicals in the protective activity of LWE, the effect of LWE on SIN-1-induced ROS generation was analyzed using the $\mathrm{H}_{2}$ DCFDA assay. SIN-1 treatment alone significantly increased intracellular ROS generation. Following treatment with LWE, ROS generation was found to decline in a dose-dependent manner. This decrease in the SIN-1-induced ROS generation may account for the decline in the observed cytoprotective effect of LWE.

Lipid peroxidation is the most extensively investigated process induced by free radicals. ROS participate in the toxic actions that lead to apoptosis in insulin-producing cells (26). In the present study, increased lipid peroxidation levels were observed in SIN-1-treated HIT-T15 cells. However, treatment with LWE resulted in a decrease in lipid peroxidation, indicating that oxidative stress-related damage was reduced in LWE-treated cells. The ability of LWE to reduce lipid peroxidation may be due to its function as a preventive antioxidant to scavenge initiating radicals.

The overproduction and consequently increased levels of free radicals may be scavenged by endogenous antioxidant enzymes, including SOD and GSH-px. In cells, SOD catalyzes the conversion of $\mathrm{O}_{2}^{-}$to $\mathrm{H}_{2} \mathrm{O}_{2}$, and $\mathrm{H}_{2} \mathrm{O}_{2}$ is further reduced to $\mathrm{H}_{2} \mathrm{O}$ by the activity of CAT or GSH-px. Pancreatic $\beta$ cells have been reported to contain low levels of endogenous antioxidant enzymes, particularly GSH-px and CAT (27). In the present study, SIN-1-treated HIT-T15 cells were shown to have decreased GSH-px and CAT activities, which may be due to the increased oxidative damage induced by SIN-1. However, LWE treatment caused an increase in the activity of these antioxidant enzymes in HIT-T15 cells, indicating that LWE reduced SIN-1-induced oxidative stress. A number of studies have reported that the overexpression of $\mathrm{CuZnSOD}$ had a protective effect in NO-induced human islets, INS-1 insulin-secreting cells (28) and alloxan- and streptozotocin-induced diabetes $(29,30)$. CAT has also exhibited a protective effect against $\mathrm{H}_{2} \mathrm{O}_{2}$ and streptozotocin-induced oxidative stress in vivo (31). Additionally, combinatorial overexpression of CAT and GSH-px has been shown to have a protective effect against ROS-induced oxidative stress through improving the activity of CuZnSOD or MnSOD (32-35).

In conclusion, the present study showed that LWE had protective activity against SIN-1-induced cell death in Syrian hamster HIT-T15 insulin-secreting cells. LWE effectively scavenged the products of SIN-1-induced intracellular ROS generation and reduced pancreatic $\beta$ cell death through increasing the activity of intracellular antioxidant enzymes, including SOD, CAT and GSH-Px. LWE also promoted insulin secretion in SIN-1-treated HIT-T15 cells.

\section{Acknowledgements}

This study was supported by the Natural Science Foundation Project of CQ CSTC (No. CSTC2012jjA80002) and the Science and Technology Research Project of Chongqing Municipal Education Commission (No. KJ121504)

\section{References}

1. Halliwell B: Reactive species and antioxidants. Redox biology is a fundamental theme of aerobic life. Plant Physiol 141: 312-22, 2006.
2. Evans JL, Goldfine ID, Maddux BA and Grodsky GM: Are oxidative stress-activated signaling pathways mediators of insulin resistance and beta-cell dysfunction? Diabetes 52: 1-8, 2003.

3. Rahimi R, Nikfar S, Larijani B and Abdollahi M: A review on the role of antioxidants in the management of diabetes and its complications. Biomed Pharmacother 59: 365-373, 2005.

4. Robertson RP and Harmon JS: Diabetes, glucose toxicity, and oxidative stress: a case of double jeopardy for the pancreatic islet beta cell. Free Radic Biol Med 41: 177-184, 2006.

5. Bell DS: Do sulfonylurea drugs increase the risk of cardiac events? CMAJ 174: 185-186, 2006.

6. Home PD, Pocock SJ, Beck-Nielsen H, Gomis R, Hanefeld M, Jones NP, Komajda M and McMurray JJ; RECORD Study Group: Rosiglitazone evaluated for cardiovascular outcomes - an interim analysis. N Engl J Med 357: 28-38, 2007.

7. Psaty BM and Furberg CD: The record on rosiglitazone and the risk of myocardial infarction. N Engl J Med 357: 67-69, 2007

8. Nathan DM: Rosiglitazone and cardiotoxicity - weighing the evidence. N Engl J Med 357: 64-66, 2007.

9. Bailey CJ and Day C: Traditional plant medicines as treatments for diabetes. Diabetes Care 12: 553-564, 1989.

10. Garcia F: Distribution and deterioration of insulin-like principle in Lagerstroemia speciosa (banaba). Acta Med Philippina 3: 99-104, 1941.

11. Klein G, Kim J, Himmeldirk K, Cao Y and Chen X: Antidiabetes and anti-obesity activity of Lagerstroemia speciosa. Evid Based Complement Alternat Med 4: 401-407, 2007.

12. Mishra Y, Khan MSY, Zafar R and Agarwal SS: Hypoglycemic activity of leaves of Lagerstroemia speciosa (L) Pers. Indian J Pharmacol 22: 174-176, 1990.

13. Priya TT, Sabu MC and Jolly CI: Free radical scavenging and anti-inflammatory properties of Lagerstroemia speciosa (L). Inflammopharmacology 16: 182-187, 2008.

14. Khan MT, Lampronti I, Martello D, Bianchi N, Jabbar S, Choudhuri MS, Datta BK and Gambari R: Identification of pyrogallol as an antiproliferative compound present in extracts from the medicinal plant Emblica officinalis: effects on in vitro cell growth of human tumor cell lines. Int J Oncol 21: 187-192, 2002.

15. Suzuki Y, Unno T, Ushitani M, Hayashi K and Kakuda T: Antiobesity activity of extracts from Lagerstroemia speciosa $\mathrm{L}$. leaves on female KK-Ay mice. J Nutr Sci Vitaminol (Tokyo) 45: 791-795, 1999.

16. Kakuda T, Sakane I, Takihara T, Ozaki Y, Takeuchi H and Kuroyanagi M: Hypoglycemic effect of extracts from Lagerstroemia speciosa L. leaves in genetically diabetic KK-AY mice. Biosci Biotechnol Biochem 60: 204-208, 1996.

17. Liu F, Kim J, Li Y, Liu X, Li J and Chen X: An extract of Lagerstroemia speciosa L. has insulin-like glucose uptake-stimulatory and adipocyte differentiation-inhibitory activities in 3T3-L1 cells. J Nutr 131: 2242-2247, 2001.

18. Liu X, Kim JK, Li Y, Li J, Liu F and Chen X: Tannic acid stimulates glucose transport and inhibits adipocyte differentiation in 3T3-L1 cells. J Nutr 135: 165-171, 2005.

19. Liu J, Sun H, Duan W, Mu D and Zhang L: Maslinic acid reduces blood glucose in KK-Ay mice. Biol Pharm Bull 30: 2075-2078, 2007.

20. Fraga CG, Leibovitz BE and Tappel AL: Lipid peroxidation measured as thiobarbituric acid-reactive substances in tissue slices: characterization and comparison with homogenates and microsomes. Free Radic Biol Med 4: 155-161, 1988.

21. Nelson DP and Kiesow LA: Enthalpy of decomposition of hydrogen peroxide by catalase at 25 degrees $\mathrm{C}$ (with molar extinction coefficients of $\mathrm{H}_{2} \mathrm{O}_{2}$ solutions in the UV). Anal Biochem 49: 474-478, 1972.

22. Marklund S and Marklund G: Involvement of the superoxide anion radical in the autoxidation of pyrogallol and a convenient assay for superoxide dismutase. Eur J Biochem 47: 469-474, 1974.

23. Hafeman DG, Sunde RA and Hoekstra WG: Effect of dietary selenium on erythrocyte and liver glutathione peroxidase in the rat. J Nutr 104: 580-587, 1974.

24. Robertson RP, Harmon J, Tran PO, Tanaka Y and Takahashi H: Glucose toxicity in beta-cells: type 2 diabetes, good radicals gone bad, and the glutathione connection. Diabetes 52: 581-587, 2003.

25. Cheng Q, Law PK, de Gasparo M and Leung PS: Combination of the dipeptidyl peptidase IV inhibitor LAF237 [(S)-1-[(3-hydroxy-1adamantyl)ammo]acetyl-2-cyanopyrrolidine] with the angiotensin II type 1 receptor antagonist valsartan [N-(1-oxopentyl)- $\mathrm{N}-[[2 \mathrm{\prime}-(1 \mathrm{H}-$ tetrazol-5-yl)-[1,1'-biphenyl]-4-yl]methyl]-L-valine] enhances pancreatic islet morphology and function in a mouse model of type 2 diabetes. J Pharmacol Exp Ther 327: 683-691, 2008. 
26. Lenzen S: Oxidative stress: the vulnerable beta-cell. Biochem Soc Trans 36: 343-347, 2008.

27. Zhang H, Ollinger $\mathrm{K}$ and Brunk U: Insulinoma cells in culture show pronounced sensitivity to alloxan-induced oxidative stress. Diabetologia 38: 635-641, 1995.

28. Moriscot C,Pattou F,Kerr-Conte J,Richard MJ,Lemarchand P and Benhamou PY: Contribution of adenoviral-mediated superoxide dismutase gene transfer to the reduction in nitric oxide-induced cytotoxicity on human islets and INS-1 insulin-secreting cells. Diabetologia 43: 625-631, 2000.

29. Kubisch HM, Wang J, Bray TM and Phillips JP: Targeted overexpression of $\mathrm{Cu} / \mathrm{Zn}$ superoxide dismutase protects pancreatic beta-cells against oxidative stress. Diabetes 46: 1563-1566, 1997.

30. Kubisch HM, Wang J, Luche R, Carlson E, Bray TM, Epstein CJ and Phillips JP: Transgenic copper/zinc superoxide dismutase modulates susceptibility to type I diabetes. Proc Natl Acad Sci USA 91: 9956-9959, 1994.

31. Xu B, Moritz JT and Epstein PN: Overexpression of catalase provides partial protection to transgenic mouse beta cells. Free Radic Biol Med 27: 830-837, 1999.
32. Amstad P, Moret R and Cerutti P: Glutathione peroxidase compensates for the hypersensitivity of $\mathrm{Cu}, \mathrm{Zn}$-superoxide dismutase overproducers to oxidant stress. J Biol Chem 269: 1606-1609, 1994

33. Lortz $\mathrm{S}$ and Tiedge M: Sequential inactivation of reactive oxygen species by combined overexpression of SOD isoforms and catalase in insulin-producing cells. Free Radic Biol Med 34: 683-688, 2003

34. Lepore DA, Shinkel TA, Fisicaro N, Mysore TB, Johnson LE, d'Apice AJ and Cowan PJ: Enhanced expression of glutathione peroxidase protects islet beta cells from hypoxia-reoxygenation. Xenotransplantation 11: 53-59, 2004.

35. Mysore TB, Shinkel TA, Collins J, Salvaris EJ, Fisicaro N, Murray-Segal LJ, Johnson LE, Lepore DA, Walters SN, Stokes R, Chandra AP, O'Connell PJ, d'Apice AJ and Cowan PJ: Overexpression of glutathione peroxidase with two isoforms of superoxide dismutase protects mouse islets from oxidative injury and improves islet graft function. Diabetes 54: 2109-2116, 2005. 